\title{
Urban Horticultural and Aquaponics for sustainability development in circular economy
}

\author{
Raffaella Vitale ${ }^{1}$
}

${ }^{1}$ Affiliation not available

March 10, 2021

\section{Introduction}

Due to rapid urbanization, population growth, climate change and environmental pollution, food security and sustainability have become a primary concern that needs to be addressed globally. According to an estimate conducted by the United Nations Department, the world population is expected to reach 9.7 billion in 2050, and a third of the world population is expected to live in cities with at least 2 million inhabitants (United Nations, Department of Economic and Social Affairs, Population Division, n.d.). The recent COVID-19 pandemic has had an impact on food supply by disrupting the food supply chain and consequently also the further increase in prices. From these circumstances emerged the exigency and the need to cover the food supply with local products. Furthermore, the growing concern about the effects of environmental pollution and the intensive use of agricultural land with pesticides and chemical compounds, the consumer is inclined to choose healthy, fresh and traceable food products (Khan et al., 2020). The interest in urban agriculture already present in recent times has strengthened during the pandemic which, globally, has triggered food insecurity.

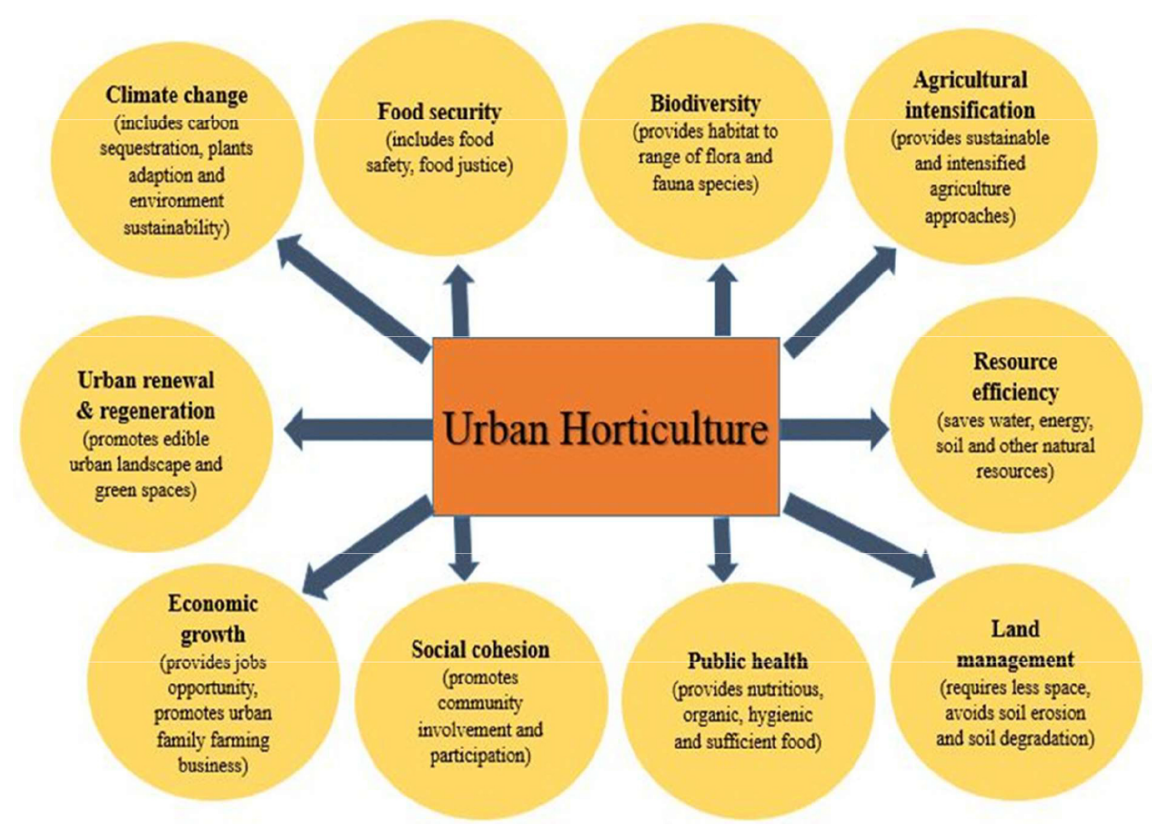

Figure 1: Social challenges of society that can be mitigated through urban agriculture (Khan et al., 2020) 


\section{Results and Discussion}

Urban agriculture can become a resilient alternative system of local food production that can translate into entirely new ways of producing food (Angotti, 2015)(Weber, 2008). Urban gardens represent the most widespread system and the renewed interest is motivated in developed countries as an instrument of social inclusion and recreational activity, this is found above all in Italy (Bartoletti, 2012). Rooftop greenhouses and indoor agriculture for plant production in existing buildings offer opportunities for savings and greater resource efficiency, in addition to the redevelopment of abandoned buildings, for example, the company Farm.one (Suman, 2019)(Farm.One, n.d.). Vertical farming refers to the production of vertical soilless plants such as hydroponic and aeroponic systems, which allow for efficient use of space and resources (Al-Kodmany, 2018). Aquaponics combines aquaculture and hydroponics, building a symbiotic relationship between fish, plants and nitrifying bacteria to create a nitrogen cycle. This cyclical and interdependent system reduces the use of conventional water and fertilizers compared to traditional agriculture ("Nutriens and Energy Balance Analysis for a Conceptual Model of a Three Loops off Grid Aquaponics", 2017). Approaches such as breeding insects or algae aim to produce new foods in order to meet the growing demand for proteins. In a study by Specht et al. (Specht et al., 2019) the different approaches to urban agriculture were analysed following the lines of the assessment of sustainability. The social impact is represented from the access and shortening of the distances of local, fresh and healthy food; from the educational effect such as hydroponics and aquaponics; from urban redevelopment and regeneration of the building fabric such as greenhouses on roofs, vertical and indoor farming and urban gardens. Negative effects concern the cost of products, the effect of green gentrification and problems related to ethics in relation to those systems that keep animals such as aquaponics. The environmental dimension, as a strong point, is represented by the efficient use of resources, the reduction of land use and pressure on agricultural land, the reduction of $\mathrm{CO} 2$ emissions and the absence of pesticide use. As for the energy efficiency aspect, in some systems such as aquaponics and indoor agriculture, a sufficiently mature level has not yet been reached. The economic benefits are represented by the high quality and the diversity of products, as well as the reduced transport costs due to the close spatial link between the production and consumption sites. The critical issues relating to profitability and initial and operating investment costs remain unaffected. In reference to the European regulatory framework, there is a need for a review of organic standards in order to encourage the further development of technology such as aquaponics and hydroponics and which would allow for premium prices to be applied in order to make business activities profitable (Asciuto et al., 2019). While about investment measures there are various programs such as Urban Innovative Actions (The Urban Lab of Europe UIA, n.d.), Milan Urban Food Policy Pact (Milan Urban Food Policy Pact, n.d.)and Reinventing Cities (C40 : Reinventing Cities, n.d.). In addition, it is worth mentioning the action plan of the European Green Deal in which urban agriculture is an integral part (Green Deal Europeo, 10AD).

As regards the progress of research on the aquaponic system, emerges an interesting study proposed by PérezUrrestarazu et al. (Pérez-Urrestarazu et al., 2019) on the optimization of small-scale aquaponic systems of FAO models by analysing the different hydroponic subsystems (nutrient film technique - NFT, floating raft DWC and vertical felt) and tested to produce lettuce and goldfish. The three systems showed different results related to fish and lettuce yield, water consumption and nitrate accumulation. Alongside this research, the study by Ong et al. (Ong et al., 2019)demonstrates the opportunity in the use of IoT technologies that allow you to monitor the remote operating parameters of the aquaponic system, offering the potential to improve food safety and sustainability, with a reduction in manpower and operating costs. 


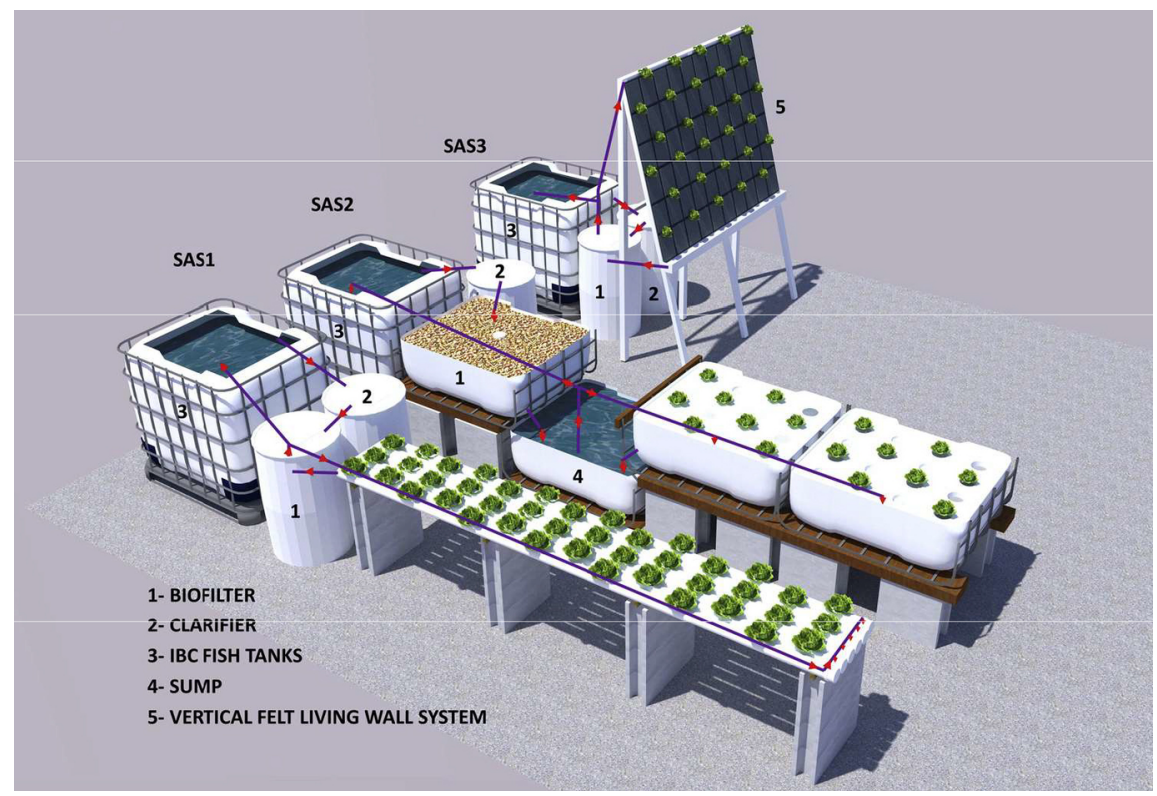

Figure 2: Schemi di SAS (Small scale Acquaponic System) (Pérez-Urrestarazu et al., 2019)

\author{
Advantages \\ SAS Earliness of plant crops \\ 1 due to the higher \\ temperature which \\ favored the nitrification \\ process.
}

SAS Higher assimilation of 2 nitrates due to direct contact with water and better thermal and chemical inertia. Suitable for plants with large root systems.

SAS Good performance with 3 ornamental plants.
Lower crop production due to poor aeration of the root zone, where the dissolved oxygen concentration was sufficient for fish growth but not optimal for plant development.

High water consumption due to direct evaporation from the felt and algae proliferation, consequently medium-low assimilation of nitrates.

Low crop production caused by lower inflow of radiation and lack of water absorption by the expanded clay, therefore low assimilation of nutrients. Obstruction of irrigation nozzles due to algae.
Improvement aspects Earliness can be improved by coloring the NFT tubes, in black by maximizing the heating of the water using sunlight in winter and vice versa in summer and making the tubes white.

Replacing the air pump with a more efficient one and increasing the number of porous stones in the hydroponic containers.

Replacement of expanded clay with perlite. To improve the system, you can replace the felt wall with the NFT and eliminate the slope.

Table 1: Evaluation of small-scale aquaponic systems according to FAO models - Advantages, Disadvantages and Improvement Aspects 
In the case of an aquaponic plant, one of the weak points in reference to the assessment of sustainability is the economic aspect concerning the initial investment cost and the dubious profitability. In a study conducted by Asciuto et al (Asciuto et al., 2019) the financial feasibility of a small-scale aquaponic pilot plant built in Palermo, having a cultivable area of 5 square meters of Lettuce and a capacity of 1 cubic meters for fish farming, (Tilapia) was analysed. The medium bed technique (MBT) is used for the hydroponic subsystem. The fish and lettuce crop was sold to the restaurant of the sports construction that housed the system. The study showed a revenue of 293.00 for one year of production. From the percentages of incidence on the operating cost, labour is the predominant element about $50 \%$, on this aspect it is possible to intervene by proposing the installation of an IoT technological system that could partially replace or minimize human work. Energy costs are $7 \%$ and can be eliminated by proposing the installation of photovoltaic panels for night power supply and to ensure the efficiency of the IoT. As far as water consumption is concerned, it is possible to apply the system patented by the Kloas et al. (Kloas et al., 2015) Study than a double recirculation system. The percentage of $9.4 \%$ relating to the cost of fish feed can be reduced with the application of microalgae biotechnology for fish feeding, highlighted in the study by Yang et al. (Yang et al., 2020). The proposals may represent possible future developments in research and involve the use of models for the optimization of the resources required in aquaponics production with the aim of identifying the productive combination to maximize income, or to deepen other economic-financial, environmental aspects. and social aspects of this activity.

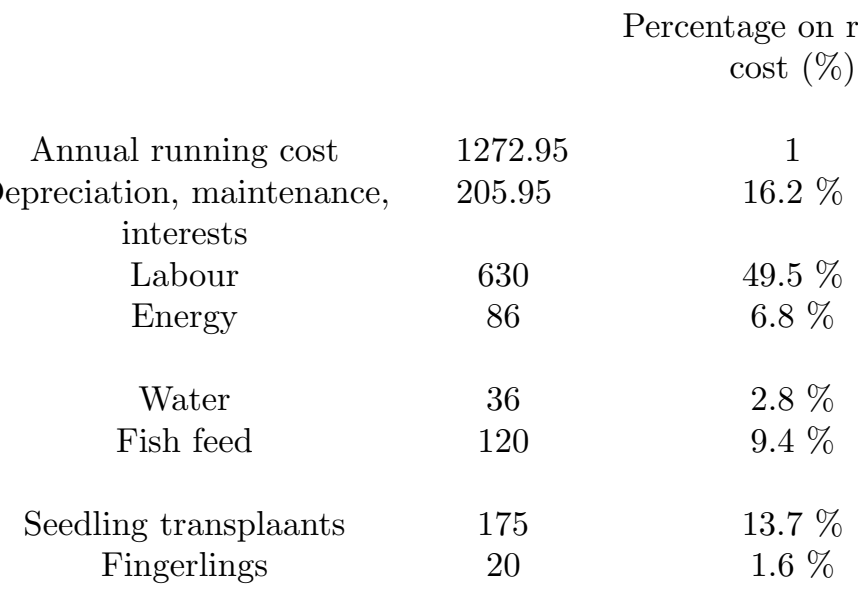

Cost reduction solutions

Installation of IoT technology

Installation of solar panels

Double recirculation system

Application of microalgal biotechnology

Table 2: Pilot aquaponic plant annual running costs (Asciuto et al., 2019) and proposals of cost reduction solutions.

In urban planning and bulding, a momentum is needed towards the integration of urban agriculture into the fabric of the city. There are few cases in which urban agriculture is fully applied in commercial and urban planning terms, such as New York in which there is the regulation in zoning, in the trade and sale of products and in business start-up (NYC Urban Agriculture, n.d.). 


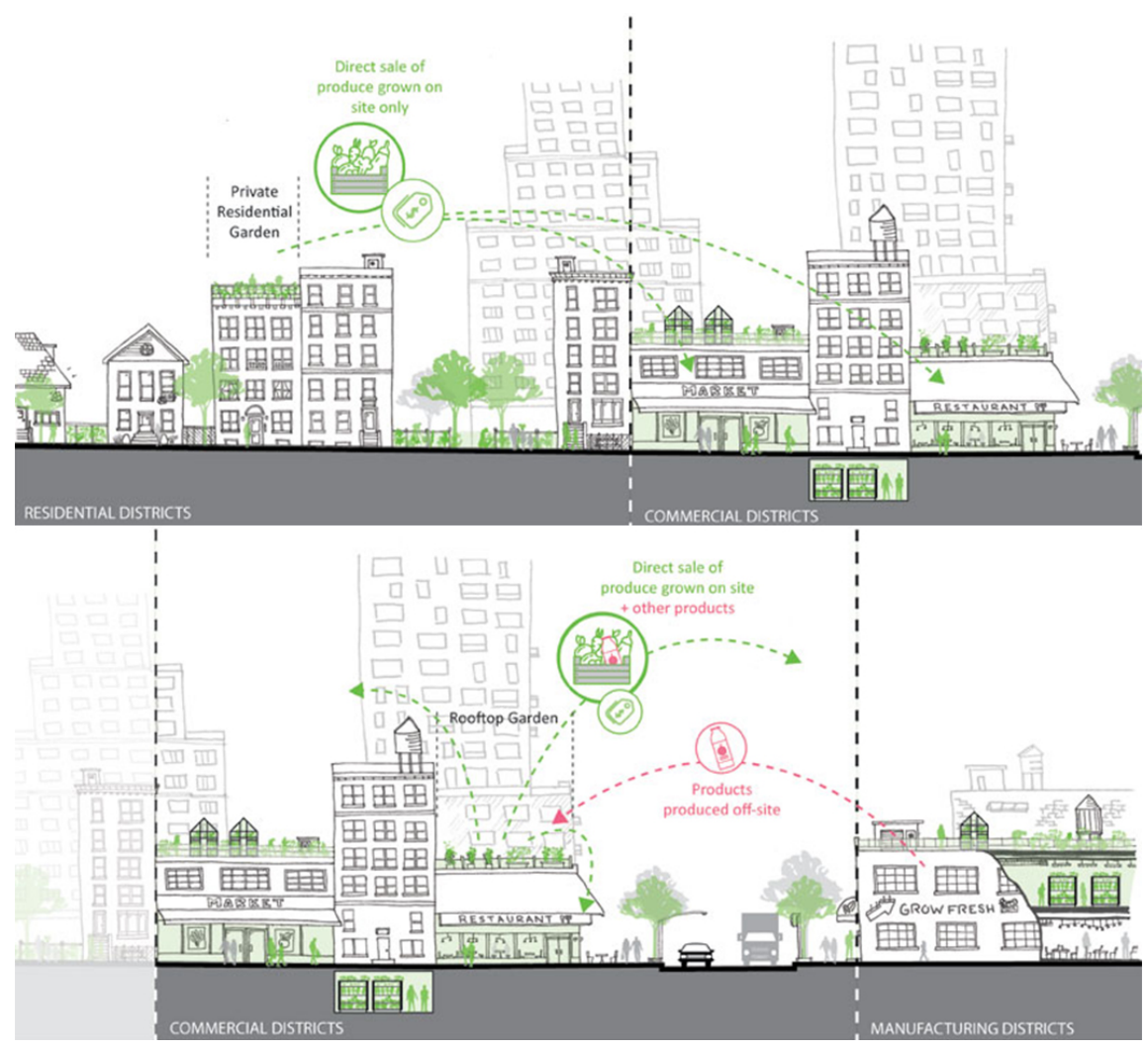

Figure 3: Sales schemes NYC Urban Agriculture (NYC Urban Agriculture, n.d.)

The experiences of London and Berlin show the willingness on the part of institutions and urban farmers to actively explore the impact of productive urban landscapes and the role of design and planning system for urban agriculture (Capital Growth, n.d.; Bohn \& Viljoen, 2012). In the Italian context, the authorities are far from applying urban agriculture with the only exception in the almost consolidated introduction of urban gardens in municipal regulations with exclusively social and non-profit use (Bonafede, 2015; De Filippi, 2017). As regards urban planning, the recent approval of the new general urban plan of the city of Bologna is an exception, which focuses attention on the green infrastructure called "Eco Rete Urbana" which aims to safeguard ecosystem services such as the green buffer strips periurban areas; private green development, also by increasing the greening of building envelopes (green roofs and walls); and the enhancement of the urban vegetable garden in the green infrastructure and urban redevelopment, and by encouraging the social function and the promotion of organic products (Piano Urbanistico Generale - Comune di Bologna, n.d.). 

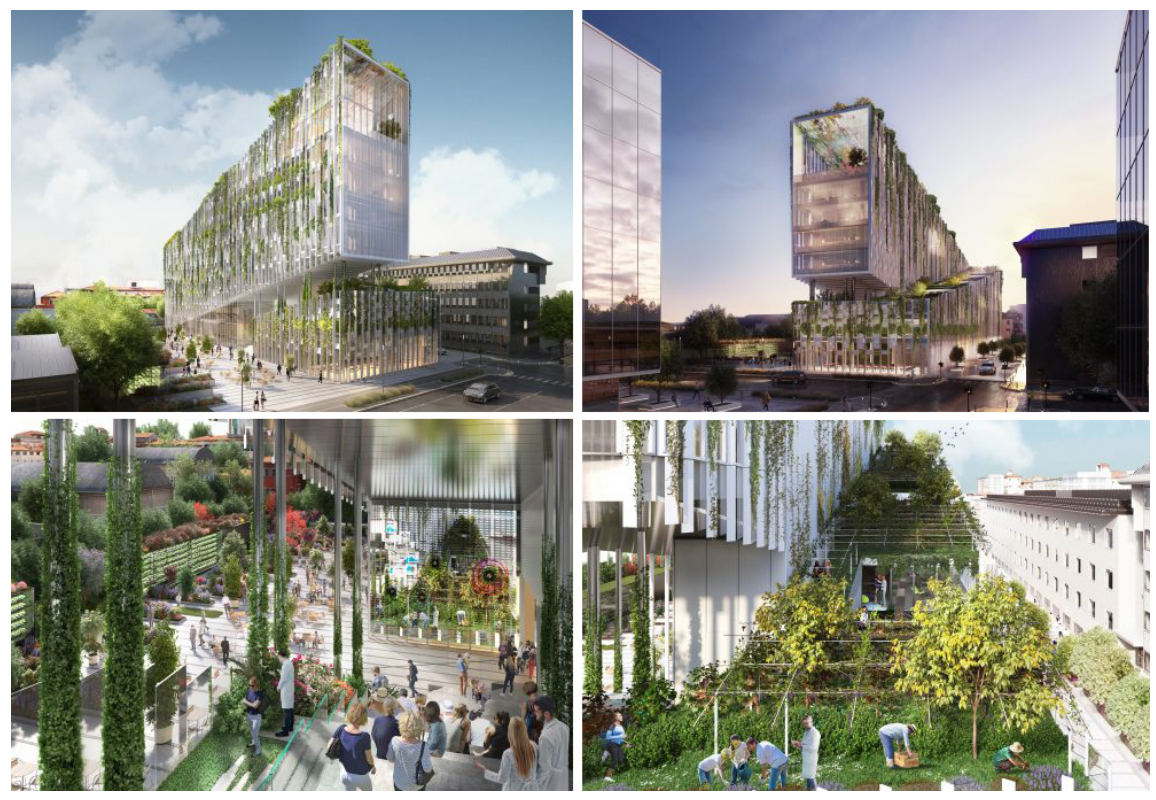

Figure 4: Carlo Ratti Associati (CRA) - Winner project of the international competition "Reinventing Cities -C40" (C40 : Reinventing Cities, n.d.)

\section{Conclusions}

Based on what has been illustrated, it is clear that urban agriculture is represent a new productive territory to be explored, useful for creating new professional outlets and new business sectors, as well as guaranteeing benefits to society by safeguarding and protecting the ecosystem and biodiversity. It should be emphasized that this agriculture does not have an exclusively social purpose, but if it is structured in an efficient and organized way, it can be economically competitive with companies in the same sector (Research for AGRI Committee - Urban and Peri-urban Agriculture in the EU, n.d.) (De Filippi, 2017) (Vignelli, 2017). As for aquaponics, although the potential is evident, it still faces further developments that hinder fully integrated production models within the framework of a circular economy (Pérez-Urrestarazu et al., 2019).

The future development of our cities will increasingly shift towards a system of food self-sufficiency which will probably see urban agriculture intensify its presence. Architecture and urban planning will have the task of changing the vision of cities and building spaces in which to allow new relationships with agricultural practices.

\section{References}

https://population.un.org/wpp/Publications/Files/WPP2019_PressRelease_EN.pdf . //population.un.org/wpp/Publications/Files/WPP2019_PressRelease_EN.pdf

https :

Urban Horticulture for Food Secure Cities through and beyond COVID-19. (2020). Sustainability, 12(22), 9592. https://doi.org/10.3390/su12229592

Urban agriculture: long-term strategy or impossible dream?. (2015). Public Health, 129(4), 336-341. https://doi.org/10.1016/j.puhe.2014.12.008

Food-Miles and the Relative Climate Impacts of Food Choices in the United States. (2008). Environmental Science 83 Technology, 42. 
Orti e giardini collettivi: pratiche grassroots e politiche urbane. (2012). Autonomie Locali e Servizi Sociali - Il Mulino - Rivisteweb, 3.

Urban Horticulture Prospective to Secure Food Provisions in Urban and Peri-Urban Environments. (2019). International Journal of Pure \& Applied Bioscience, 7(3), 133-140. https://doi.org/10.18782/23207051.7469

https://farm.one/. https://farm.one/

The Vertical Farm: A Review of Developments and Implications for the Vertical City. (2018). Buildings, 8(2), 24. https://doi.org/10.3390/buildings 8020024

(2017). Water, 8.

How Will We Eat and Produce in the Cities of the Future? From Edible Insects to Vertical Farming-A Study on the Perception and Acceptability of New Approaches. (2019). Sustainability, 11(16), 4315. https: //doi.org/10.3390/su11164315

A financial feasibility study of an aquaponic system in a Mediterranean urban context. (2019). Urban Forestry \& Urban Greening, 38, 397-402. https://doi.org/10.1016/j.ufug.2019.02.001

https://www.uia-initiative.eu/en. https://www.uia-initiative.eu/en/home

https://www.milanurbanfoodpolicypact.org/. https://www.milanurbanfoodpolicypact.org/

https://www.c40.org/programmes/reinventing_cities. https://www.c40.org/programmes/ reinventing_cities

(10AD). https://ec.europa.eu/info/strategy/priorities-2019-2024/european-green-deal_it. https://ec.europa.eu/info/strategy/priorities-2019-2024/european-green-deal_it

Suitability and optimization of FAO's small-scale aquaponics systems for joint production of lettuce (Lactuca sativa) and fish (Carassius auratus). (2019). Aquacultural Engineering, 85, 129-137. https://doi.org/10. $1016 / j$. aquaeng. 2019.04.001

Intelligent Outdoor Aquaponics with Automated Grow Lights and Internet of Things. (2019, August). 2019 IEEE International Conference on Mechatronics and Automation (ICMA). https://doi.org/10.1109/ icma. 2019.8816577

A new concept for aquaponic systems to improve sustainability increase productivity, and reduce environmental impacts. (2015). Aquaculture Environment Interactions, 7(2), 179-192. https://doi.org/10. $3354 /$ aei00146

Emerging trends of culturing microalgae for fish-rearing environment protection. (2020). Journal of Chemical Technology 83 Biotechnology, 96(1), 31-37. https://doi.org/10.1002/jctb.6563

https://www1.nyc.gov/site/agriculture/index.page. https://www1.nyc.gov/site/agriculture/ index.page

https://www . capitalgrowth.org/. https://www . capitalgrowth.org/home/

Chapter 38 The CPUL City Toolkit: planning productive urban landscapes for European cities. (2012). In Sustainable food planning: evolving theory and practice (pp. 479-494). Wageningen Academic Publishers. https://doi.org/10.3920/978-90-8686-187-3_38

Mani verdi per la città. Scenari di agricoltura urbana multifunzionale nella Piana dei colli a Palermo Scienze del Territorio. (2015). Scienze Del Territorio - Ricostruire La Città, 3. https://oajournals . fupress.net/index.php/sdt/article/view/8508 
Agricoltura come dispositivo di rigenerazione urbana. Un'esperienza torinese: OrtiAlti a Casa Ozanam Ri-Vista. Research for landscape architecture. (2017). Ri-Vista, 1. https://oaj.fupress.net/index. $\mathrm{php} / \mathrm{ri}$-vista/article/view/2748

http://dru.iperbole.bologna.it/categorie-pianificazione/piano-urbanistico-generale-pug. http://dru.iperbole.bologna.it/categorie-pianificazione/piano-urbanistico-generale-pug

https://www. europarl . europa.eu/RegData/etudes/STUD/2018/617468/IPOL_STU(2018)617468_EN . pdf . https://www . europarl . europa.eu/RegData/etudes/STUD/2018/617468/IPOL_STU(2018)617468_ EN.pdf

Agricoltura urbana e architetti, un matrimonio possibile?. (2017). Ordine - Vertical (and Urban) Farming. 